\title{
Cytotoxic Activity of Casearborin C Isolated from Casearia corymbosa
}

\author{
María Leonor Vila-Luna, ${ }^{1}$ Rosa Esther Moo-Puc, ${ }^{2}$ Luis Wiliunfo Torres-Tapia, ${ }^{1}$ Sergio Rubén \\ Peraza-Sánchez ${ }^{1, *}$ \\ ${ }^{1}$ Unidad de Biotecnología, Centro de Investigación Científica de Yucatán (CICY), Calle 43 \#130 (32 y 34), \\ Col. Chuburná de Hidalgo, Mérida, Yucatán, México 97205. \\ ${ }^{2}$ Unidad de Investigación Médica, Centro Médico Ignacio García Téllez, Instituto Mexicano del Seguro \\ Social (IMSS), Calle 41 No. 439, Col. Industrial, Mérida, Yucatán, México 97150.
}

* Corresponding author: Sergio R. Peraza-Sánchez, Tel. (999) 942-8330, Ext. 264, e-mail: speraza@cicy.mx

Received November $9^{\text {th }}, 2017$; Accepted February $23^{\text {th }}, 2018$.

DOI: http://dx.doi.org/10.29356/jmcs.v62i3.370

\begin{abstract}
Casearborin c (1), syringic acid (2), ent-3ß-hydroxy-(-)-13-epi-manoyl oxide (3), ent-(-)-13-epimanoyl oxide (4), ent-(-)-kaur-16-en-19-oic acid (5), and $\gamma$-sitosterol (6) were isolated from Casearia corymbosa stem bark. Only casearborin c showed cytotoxic activity on HeLa and SiHa cancer cell lines. This work contributes to the description of three compounds (1-3) newly isolated from C. corymbosa and highlights that casearborin c, a clerodane-type diterpene, is responsible for the cytotoxic activity shown in the original methanol extract of this species.
\end{abstract}

Keywords: Salicaceae; Casearia corymbosa; cytotoxic activity; diterpenes; clerodanes; casearborin c.

Resumen. Casearborina c (1), ácido siríngico (2), óxido de ent-3ß-hidroxi-(-)-13-epi-manoilo (3), óxido de ent-(-)-13-epi-manoilo (4), ácido ent-(-)-kaur-16-en-19-oico (5) y $\gamma$-sitosterol (6) se aislaron de la corteza del tallo de Casearia corymbosa. Sólo casearborina c mostró actividad citotóxica en las líneas de células cancerígenas HeLa y SiHa. Este trabajo describe tres compuestos (1-3) aislados por primera vez de $C$. corymbosa y destaca que casearborina c, un diterpeno de tipo clerodano, es responsable de la actividad citotóxica del extracto metanólico de esta especie.

Palabras clave: Salicaceae; Casearia corymbosa; actividad citotóxica; diterpenos; clerodanos; casearborina c.

\section{Introduction}

Cancer is one of the major health problems in the world that urgently requires of an effective cure. Plants play a very important role in finding new treatments for this disease, since about $50 \%$ of the drugs available to treat cancer come from natural products or their derivatives [1,2]. The genus Casearia includes 180 species [3] and belongs to Salicaceae family. This family is constituted of 54 genera and 1,200 species, composed of trees or bushes of cosmopolitan distribution [4], and considered as source of clerodane-type diterpenes [5-7]. In the Yucatan peninsula there are four species of the genus Casearia [8], including Casearia corymbosa Kunth. This species is used in Mayan traditional medicine as anti-inflammatory, antisyphilitic, carminative, antitussive, against asthma, erysipelas and skin wounds [9]. There are very few chemical studies on this species $[10,11]$. Previously, we evaluated the cytotoxic activity of a $\mathrm{MeOH}$ extract of C. corymbosa stem bark, showing activity against $\mathrm{HeLa}$ and $\mathrm{SiHa}$ human cancer cell lines [12]. In a continuing investigation on bioactive molecules from medicinal plants of the Yucatan peninsula, we have undertaken the isolation of metabolites from a cytotoxic $\mathrm{MeOH}$ extract of $C$. corymbosa stem bark. 


\section{Experimental procedures}

IR spectra were taken with a Nicolet 8700 (FTIR) Thermo Scientific spectrometer using KBr disks. NMR spectra $\left({ }^{1} \mathrm{H},{ }^{13} \mathrm{C}\right)$ were acquired on a Bruker Avance Ultrashield $400(400 \mathrm{MHz})$ spectrometer and on a Varian/Agilent Premium Compact $600 \mathrm{MHz}$ spectrometer. Low resolution mass spectra (MS) were taken on an Agilent Technologies $6890 \mathrm{~N}$ gas chromatograph coupled to a 5975B mass spectrometer (GC-MS). Column chromatography was carried out either over silica gel $\left(60 \AA, 0.75 \mathrm{~cm}^{3} / \mathrm{g}, 2-25 \mu \mathrm{m}\right.$, Sigma-Aldrich; 60 $\AA, 0.75 \mathrm{~cm}^{3} / \mathrm{g}, 70-230$ mesh, Merck) or Sephadex LH-20 (Sigma-Aldrich). TLC was performed on precoated silica gel plates ( $60 \AA, F_{254}$, Merck). Spots on TLC were visualized under UV light in a Chromato-Vue ${ }^{\circledR}$ C-75 cabinet and by spraying phosphomolybdic acid or oleum reagents followed by heating. The optical density of the developed plates with sulforhodamine B (SRB) was read in a ThermoSpectronic spectrophotometer at 560 nm.

Plant material. Stem bark of C. corymbosa was collected in November 2013 at Othón P. Blanco, Quintana Roo (Mexico). The plant material was identified by the taxonomist Paulino Simá-Polanco from the Unit of Natural Resources of the Scientific Research Center of Yucatan (CICY). A specimen was deposited at CICY's U Najil Tikin Xiw herbarium with the voucher number P.Simá 3562.

Extraction and isolation. The stem bark $(1.327 \mathrm{Kg})$ of $C$. corymbosa was dried, grounded, and extracted by maceration with $\mathrm{MeOH}(4 \mathrm{~L}, 3 \times)$ at room temperature for $24 \mathrm{~h}$. The $\mathrm{MeOH}$ extract $(1 \mathrm{~A}, 112.5 \mathrm{~g})$ was then diluted with $\mathrm{MeOH}-\mathrm{H}_{2} \mathrm{O}$ (3:1) and partitioned successively with hexane $(\mathrm{Hx}), \mathrm{CH}_{2} \mathrm{Cl}_{2}$, and $\mathrm{EtOAc}$ $(3 \times$ each) to afford the corresponding fractions $2 \mathrm{~A}(30.7 \mathrm{~g}), 2 \mathrm{~B}(6.6 \mathrm{~g})$, and $2 \mathrm{C}(16.3 \mathrm{~g})$. Fractions $2 \mathrm{~A}$ and $2 \mathrm{~B}$ were cytotoxic. The active fraction $2 \mathrm{~B}$ was subjected to vacuum liquid chromatography (VLC) using mixtures of $\mathrm{Hx} / \mathrm{EtOAc}$ of increasing polarity, obtaining nine fractions (3A-3I). Fraction 3D $(0.717 \mathrm{~g})$ was subjected to Sephadex LH-20 chromatography with $\mathrm{CH}_{2} \mathrm{Cl}_{2} / \mathrm{MeOH}$ (1:1), to obtain three fractions (4A-4C). Fraction 4B $(0.497 \mathrm{~g})$ was purified in an open chromatographic column (CC) with $\mathrm{CH}_{2} \mathrm{Cl}_{2} / \mathrm{EtOAc}(9.5: 0.5,9: 1$, and 8:2), obtaining eight fractions $(5 \mathrm{~A}-5 \mathrm{H})$. Fraction $5 \mathrm{E}(0.042 \mathrm{~g})$ was subjected to two consecutive $\mathrm{CC}$ with $\mathrm{CH}_{2} \mathrm{Cl}_{2} / \mathrm{EtOAc}(8: 2)$ and $(7: 3)$ until compound $1(8 \mathrm{mg})$ was isolated. Fraction $3 \mathrm{E}(0.383 \mathrm{~g})$ was subjected to Sephadex LH-20 with $\mathrm{CH}_{2} \mathrm{Cl}_{2} / \mathrm{MeOH}$ (1:1), yielding six fractions (6A-6F). Fraction 6C $(0.061 \mathrm{~g})$ was subjected to $\mathrm{CC}$ with $\mathrm{CH}_{2} \mathrm{Cl}_{2} / \mathrm{EtOAc}(8: 2)$, obtaining compound $2(6.7 \mathrm{mg})$. The active fraction $2 \mathrm{~A}$ was subjected to VLC using $\mathrm{Hx} / \mathrm{CH}_{2} \mathrm{Cl}_{2}$ and $\mathrm{CH}_{2} \mathrm{Cl}_{2} / \mathrm{EtOAc}$ of increasing polarity, yielding eight fractions (7A$7 \mathrm{H})$. Fraction 7F (10.6 g) was subjected to VLC using $\mathrm{Hx} /$ acetone (An) of increasing polarity, obtaining six fractions $(8 \mathrm{~A}-8 \mathrm{~F})$. Fraction 8A (3.08 g) was subjected to Sephadex $\mathrm{LH}-20$ eluted with $\mathrm{Hx} / \mathrm{CH}_{2} \mathrm{Cl}_{2} / \mathrm{MeOH}$ (2:1:1) until six fractions were obtained (9A-9F). Fraction 9D (1.65 g) was subjected to CC with $\mathrm{Hx} / \mathrm{An}(9: 1)$ to obtain compound $3(467.1 \mathrm{mg})$. Fraction 9B $(0.623 \mathrm{~g})$ was subjected to three consecutive $\mathrm{CC}$ with $\mathrm{Hx} / \mathrm{An}$ $(9: 1)$ and $\mathrm{Hx} / \mathrm{EtOAc}(9: 1)$ to obtain compound $6(12.5 \mathrm{mg})$. Fraction $7 \mathrm{~B}(3.87 \mathrm{~g})$ was subjected to VLC using consecutively $\mathrm{Hx} / \mathrm{CH}_{2} \mathrm{Cl}_{2}$ and $\mathrm{CH}_{2} \mathrm{Cl}_{2} / \mathrm{EtOAc}$ of increasing polarity to yield seven fractions (10A-10G). Fraction 10B $(0.298 \mathrm{~g})$ was subjected to two consecutive $\mathrm{CC}$ with $\mathrm{Hx} / \mathrm{EtOAc}(9.9: 0.1)$ and $\mathrm{Hx} / \mathrm{CH}_{2} \mathrm{Cl}_{2}$ (7.8:2.2) to obtain compound $4(81.5 \mathrm{mg})$. Fraction $7 \mathrm{D}(6.55 \mathrm{~g})$ was subjected to VLC using $\mathrm{Hx} / \mathrm{CH}_{2} \mathrm{Cl}_{2}$ and $\mathrm{Hx} /$ EtOAc of increasing polarity, giving six fractions $(11 \mathrm{~A}-11 \mathrm{~F})$. Fraction $11 \mathrm{~A}(1.07 \mathrm{~g})$ was subjected to Sephadex LH-20 with $\mathrm{CH}_{2} \mathrm{Cl}_{2} / \mathrm{MeOH}$ (1:1), yielding compound 5 (189.1 mg).

\section{Biological activities}

Cell culture. Cell lines of cervix adenocarcinoma (HeLa, ATCC-CCL-2), cervix squamous carcinoma (SiHa, ATCC-HTB-35), and normal green monkey kidney cell line (Vero, ATCC-CCL-81), from the American Type Culture Collection (ATCC) were maintained in DMEM medium (Gibco), supplemented with fetal bovine serum $(10 \%, \mathrm{v} / \mathrm{v}), 10,000 \mathrm{U} / \mathrm{mL}$ penicillin $\mathrm{G}, 100 \mathrm{mg} / \mathrm{mL}$ streptomycin, and $2.5 \mathrm{mg} / \mathrm{mL}$ amphotericin $\mathrm{B}$ in an atmosphere with $95 \%$ of humidity and $5 \% \mathrm{CO}_{2}$ at $37^{\circ} \mathrm{C}$.

Cytotoxicity assay. Sulforhodamine B (SRB) colorimetric assay was used to estimate cell number by staining total cellular protein with SRB dye [25]. Cells were seeded in 96-well plates (Costar) at a concentration of $5 \times 10^{4}$ cells per well and incubated for $24 \mathrm{~h}$ to $48 \mathrm{~h}$; when cells reached $100 \%$ confluence, the medium was replaced with new medium without fetal bovine serum (FBS) and the cells were treated with either the organic extract or compound. Previously, a stock of the extract or compound dissolved in dimethylsulfoxide was prepared at a concentration of $10 \mathrm{mg} / \mathrm{mL}$ before being added to the culture medium at concentrations of $50,25,12.5$, and $6.25 \mu \mathrm{g} / \mathrm{mL}$. After $48 \mathrm{~h}$ of incubation, cells were fixed with $100 \mu \mathrm{L}$ of trichloroacetic acid (TCA, Aldrich) for $30 \mathrm{~min}$ at $4{ }^{\circ} \mathrm{C}$ and then $100 \mu \mathrm{L}$ SRB $(0.1 \%$ SRB in $1 \%$ acetic acid, 
Sigma) were added to each well and incubated at room temperature for $15 \mathrm{~min}$; later the supernatant was retired and plates were washed twice with acetic acid (1\%). Subsequently, $100 \mu \mathrm{L}$ of Tris-base $(10 \mathrm{mM})$ were added to solubilize the dye and optical density was read on a spectrophotometer at $560 \mathrm{~nm}$ using an ELISA reader (model 450, Bio-Rad, USA). Untreated cells were used as negative control and docetaxel as positive control. The $\mathrm{CC}_{50}$ values were obtained by nonlinear regression using GraphPad-Prism 4.00 software. We also carried out an antiproliferative assay using SRB; the method is the same as that for the cytotoxicity assay, except that when cells reached $70-80 \%$ confluence the medium was replaced with DMEM $10 \%$ FBS to induce cellular proliferation during extract treatments.

\section{Results and Discussion}

The crude $\mathrm{MeOH}$ extract was subjected to a bioguided fractionation using a HeLa cancer cell line in the in vitro assay to evaluate fractions and pure compounds. Then, the $\mathrm{MeOH}$ extract was submitted to liquidliquid partition, being the hexane and dichloromethane fractions the more active, from which casearborin $\mathrm{c}$ (1), syringic acid (2), ent-33-hydroxy-(-)-13-epi-manoyl oxide (3), ent-(-)-13-epi-manoyl oxide (4), ent-(-)kaur-16-en-19-oic acid (5), and $\gamma$-sitosterol (6) were isolated, being 1 and 3-5 diterpenes. Due to its high yield and having an $\mathrm{OH}$ group in its structure, $\mathbf{3}$ was subjected to acetylation and oxidation derivatization to obtained 7 and 8, respectively. Structures of 1-6 were confirmed by comparison of their RMN spectral data to those published in the literature (Fig. 1), while structures of $\mathbf{7}$ and $\mathbf{8}$ (Fig. 2) were confirmed by comparison of their IR and NMR spectral data with those of the original sample (compound $\mathbf{3}$ ).

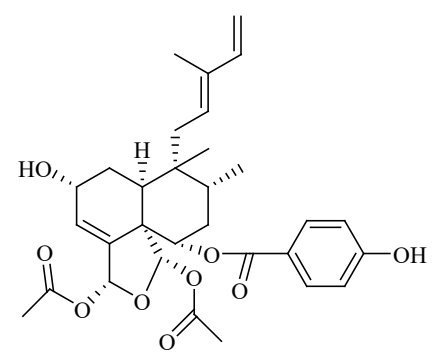

1

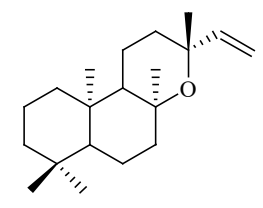

4<smiles>COc1cc(C(=O)O)cc(OC)c1O</smiles>

2

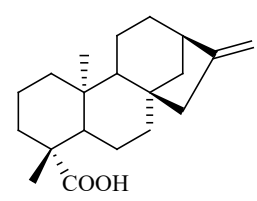

5

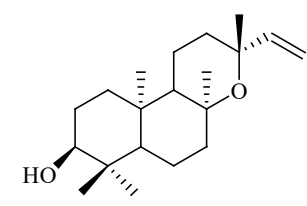

3

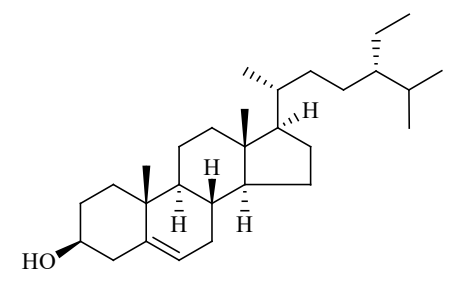

6

Fig. 1. Compounds isolated from C. corymbosa stem bark.

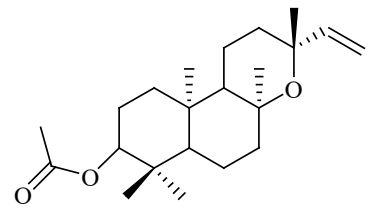

7

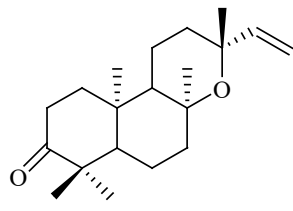

8

Fig. 2. Acetylated and oxidized derivatives of compound 3. 
Casearborin c (1), a clerodane-type diterpene, was isolated for the first time from Casearia arborea

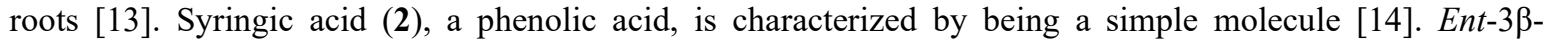
hydroxy-(-)-13-epi-manoyl oxide (3) is a labdane-type diterpene derived from manoyl oxide [15,16]. The chemical shift value of $\mathrm{H}-3$ at $\delta 3.22(1 \mathrm{H}$, dd, $J=4.5,11.6 \mathrm{~Hz})$ of 3 confirmed that the $\mathrm{OH}$ is axial and made possible to establish that the structure of $\mathbf{3}$ actually corresponds to the isomer of ent-3 $\alpha$-hydroxy-(-)-13-epimanoyl oxide [17], formerly isolated from C. corymbosa [10]. This is the first report of compounds 1-3 from C. corymbosa. Compounds 4, a labdane-type diterpene [18,19], and $\mathbf{5}$, a kaurene-type diterpene [20,21], have previously been isolated from C. corymbosa [10]. $\gamma$-Sitosterol (6), a common sterol in plants [22], was identified by comparison of its GC-MS mass spectrum with that from the NIST database.

Casearborin c (1) exhibited high cytotoxic activity on HeLa cancer cell line and low cytotoxic activity on SiHa cell line and normal Vero cell line, with mean cytotoxic concentration values of 13.44, 77.36, and $50.26 \mu \mathrm{M}$, respectively, displaying low selectivity on HeLa line (3.7) and no selectivity on SiHa line (0.6) (Table 1). This compound has been evaluated on melanoma (LOX) and glioblastoma (SF539) cell lines, reporting a cytotoxic effect [13]. The isolated compounds had no antiproliferative activity at the concentrations evaluated (data not included). Syringic acid (2) has displayed cytotoxic activity on two colorectal cancer cell lines (SW1116 and SW837) [23]. Ent-3ß-hydroxy-(-)-13-epi-manoyl oxide (3) has been evaluated on HeLa cell line by Su et al. [24], showing low cytotoxic activity. In the present study we also evaluated 3 against HeLa, but no activity was obtained; however, we tested lower concentrations than those used by $\mathrm{Su}$ et al. Compounds 5 and 7 showed cytotoxic activities only at the highest concentration (50 $\mu \mathrm{g} / \mathrm{mL}$ ) on the cell lines evaluated, while $\mathbf{4}, \mathbf{6}$, and $\mathbf{8}$ presented no effect.

Table 1. Cytotoxic activity of casearborin $\mathrm{c}$ in different cell lines.

\begin{tabular}{|l|c|c|c|}
\hline \multirow{2}{*}{ Compound } & \multicolumn{3}{|c|}{ CC $_{50} \boldsymbol{\mu} \mathbf{M}^{\mathbf{a}}$ (SI) $^{\mathbf{b}}$} \\
\cline { 2 - 4 } & Vero & HeLa & SiHa \\
\hline Casearborin c & 50.26 & $13.44(3.7)$ & $77.36(0.6)$ \\
\hline Docetaxel & 1.36 & $0.25(5.5)$ & $0.22(6.1)$ \\
\hline
\end{tabular}

\section{Conclusions}

The genus Casearia is considered a rich source of diterpenes of the clerodane type, which are suggested as the main responsible for the cytotoxic activity reported in different cancer cell lines $[5,13]$. Among the isolated metabolites from C. corymbosa in the present study, there were diterpenes of clerodane, labdane, and kaurene types, as well as a phenolic acid and a sterol. This study highlights the fact that the clerodane-type diterpenes are the only ones responsible for the observed cytotoxic activity in the crude $\mathrm{MeOH}$ extract, since casearborin $\mathrm{c}$ was exclusively the one that showed activity; also, this work contributes to the phytochemical knowledge of $C$. corymbosa, since casearborin c, syringic acid, and ent-33-hydroxy-(-)-13epi-manoyl are being reported for the first time from this species.

\section{Acknowledgements}

This work was supported by grant 2011-785-004 (IMSS). We thank Paulino Simá-Polanco, from the Unit of Natural Resources (CICY), for his help in the identification of the plant material; to the laboratory LANNBIO of Cinvestav-Merida (Mexico), for NMR spectra; and Fundación Medina at Granada, Spain, for LC-HRMS analysis. 


\section{References}

1. Balunas, M. J.; Kinghorn, A. D. Life Sci. 2005, 78, 431-441.

2. Newman, D. J.; Cragg, G. M. J. Nat. Prod. 2007, 70, 461-477.

3. Nee, M., in: Flora de Veracruz, Flacourtiaceae, Fasc. 111, 1999, 1-15.

4. http://www.mobot.org/MOBOT/research/APweb/, accessed August 2017.

5. Sai Prakash, C.V.; Hoch, J. M.; Kingston, D. G. I. J. Nat. Prod. 2002, 65, 100-107.

6. Vieira Júnior, G. M.; De Oliveira Gonçalves, T.; Regasini, L. O.; Pinheiro Ferreira, P. M.; Do Ó Pessoa, C.; Costa Lotufo, L. V.; Buzanelli Torres, R.; Boralle, N.; Da Silva Bolzani, V.; Cavalheiro, A. J. J. Nat. Prod. 2009, 72, 1847-1850.

7. Gonzaga dos Santos, A.; Pinheiro Ferreira, P. M.; Vieira Júnior, G. M.; Perez, C. C.; Gomes Tininis, A.; Silva, G. H.; Da Silva Bolzani, V.; Costa Lotufo, L. V.; Do Ó Pessoa, C.; Cavalheiro, A. J. Chem. Biodiv. 2010, 7, 205-215.

8. http://www.cicy.mx/sitios/flora\%20digital/indice tax especies.php?genero=Casearia, accessed August 2017.

9. Arellano Rodriguez, J.; Flores Guido, J.; Tun Garrido, J.; Cruz Bojorquez, M., in: Nomenclatura, Forma de Vida, Uso, Manejo y Distribución de las Especies Vegetales de la Península de Yucatán, Flacourtiaceae, Verbenaceae, Ed., Universidad Autónoma de Yucatán Press, México, 2003, $238,601$.

10. Khan, M. R.; Gray, A. I.; Sadler, I. H.; Waterman, P. G. Phytochemistry 1990, 29, 3591-3595.

11. Chen, T.-B.; Wiemer, D. F. J. Nat. Prod. 1991, 54, 1612-1618.

12. Caamal-Fuentes, E.; Torres-Tapia, L. W.; Simá-Polanco, P.; Peraza-Sánchez, S. R.; Moo-Puc, R. J. Ethnopharmacol. 2011, 135, 719-724.

13. Beutler, J. A.; McCall, K. L.; Herbert, K.; Herald, D. L.; Pettit, G. R.; Johnson, T.; Shoemaker, R. H.; Boyd, M. R. J. Nat. Prod. 2000, 63, 657-661.

14. Cho, J.-Y.; Yang, X.; Park, K.-H.; Park, H. J.; Park, S.-Y.; Moon, J.-H.; Ham, K.-S. Food Sci. Biotechnol. 2013, 22, 1547-1557.

15. Fraga, B. M.; González, P.; Guillermo, R.; Hernández, M. G.; Rovirosa, J. Phytochemistry 1989, 28, 1851-1854.

16. Demirezer, L. O.; Guvenalp, Z.; Kuruuzum-Uz, A; Kazaz, C. Chem. Nat. Compd. 2012, 48, $337-338$.

17. González, A. G.; Fraga, M. B.; Hernández, M. G.; Luis, J. G. Phytochemistry 1973, 12, 1113-1116.

18. González, A. G.; Arteaga, J. M.; Bretón, J. L.; Fraga, B. M. Phytochemistry 1977, 16, 107-110.

19. Kenmoku, H.; Sugai, T.; Yajima, H.; Sassa, T. Biosci. Biotechnol. Biochem. 2004, 68, 2418-2420.

20. Kakuta, H.; Seki, T.; Hashidoko, Y.; Mizutani, J. Biosci. Biotechnol. Biochem. 1992, 56, 1562-1564.

21. Boeck, P.; Sá, M. M.; De Souza, B. S.; Cercená, R.; Escalante, A. M.; Zachino, S. A.; Filho, V. C.; Yunes, R. A. J. Braz. Chem. Soc. 2005, 16, 1360-1366.

22. Myant, N. B., in: The Biology of Cholesterol and Related Esteroids, Ed., William Heinenmann Medical Books Ltd, London, 1981, 3-4.

23. Abaza, M.-S.; Al-Attiyah, R.; Bhardwaj, R.; Abbadi, G.; Koyippally, M.; Afzal, M. Pharm. Biol. 2013, 51, 1110-1124.

24. Su, D.; Yang, X.-Y.; Feng, X.; Shang, M.-Y.; Cai S.-Q. Molecules 2014, 19, 18966- 18979.

25. Blumenthal, R. D., in: Methods in Molecular Medicine, Chemosensitivity, Vol. 1, Ed., Humana Press, Inc., Totowa, New Jersey, 2005, 39-48. 